\title{
Realizácia STEM aktivít v školských výchovno-vzdelávacích zariadeniach
}

\author{
Michaela Bieliková
}

\begin{abstract}
Abstrakt: Predkladaná teoretická śtúdia sa zameriava na možnosti realizácie STEM (science, technology, engineering, and mathematics) aktivit v neformálnom vzdelávani, konkrétne v školských kluboch deti (SR) a školskej družine (školni družina- ČR). V prispevku sa zameriavame na spôsob realizácie a hodnotenia STEM aktivit v poškolských zariadeniach a programoch (after school clubs, out of school clubs, afterschool program), ktoré sa realizujú v zahraniči, ako aj na vplyv týchto aktivit na samotného žiaka (jeho prospech, správanie, socializáciu a pod.).

Priestor, $v$ ktorom vidime uplatnenie týchto aktivit v našom (slovenskom a českom) prostredi, je v rámci viacerých režimových činnosti, t.j. vodpočinkových, záujmových ${ }^{1}$ a pohybovo-rekreačných činnostiach, konkrétne však v prírodovedno-environmentálnej tematickej oblasti výchovy (zájmové činnosti prírodovèdnè-ekologické) a pracovno-technickej tematickej oblasti výchovy (zájmové činnosti pracovnè-technické) zarad'ovaných do spomenutých činností. V týchto zariadeniach vidime rozširené možnosti (priestorové aj časové) pri realizácii STEM aktivit v porovnaní s klasickým vyučovaním, kde je pedagóg obmedzený predovšetkým triednohodinovým systémom.
\end{abstract}

Klúčové slová: hodnotenie, poškolské programy, STEM aktivity, školni družina, školský klub detí.

\section{ÚvOD}

Pre neformálne vzdelávanie je charakteristické, že jeho ukončenie nie je zavŕšené získaním oficiálnych dokladov (ako napr. vysvedčenie žiaka vo formálnom vzdelávaní) a zvyčajne sa realizuje popri hlavných prúdoch vzdelávania a odbornej prípravy
(Memorandum o celoživotnom vzdelávaní sa, 2000). Medzi neformálne vzdelávanie zarad'ujeme aj školské výchovno-vzdelávacie zariadenia ${ }^{2}$ (školské kluby, centrum volného času, školský internát - SR) a „školská zařízení pro zájmové vzděláváni“"3 (stř̌edisko volného času, školní klub, školní družina - ČR). V našom príspevku

\footnotetext{
${ }^{1}$ Záujmové činnosti sa nad’alej realizujú v Českej republike. Na Slovensku boli od roku 2013 vypustené z ŠKD a presunuté pod centrá vol'ného času.

${ }^{2}$ Pozri bližšie zákon č. 245/2008 Z. z., o výchove a vzdelávaní (školský zákon) a o zmene a doplnení niektorých zákonov, dostupné z www.zakonypreludi.sk

${ }^{3}$ Pozri bližšie vyhláška č. 74/2005 Sb., o zájmovém vzdělávání, dostupné na https://www.zakonyprolidi.cz/cs/2005-74.
} 
sa zameriame na zariadenia poskytujúce starostlivost́ o žiakov v čase mimo vyučovania na prvom stupni $Z \check{S}$, konkrétne na školské kluby detí (SR, dalej už len ŠKD) a školní družiny (ČR, d’alej už len ŠD).

$\mathrm{V}$ texte pracujeme $s$ označením poškolské programy a poškolské zariadenia, $s$ ktorými sa stretávame $\mathrm{v}$ zahraničnej literatúre (afterschool program, after school clubs, out of school clubs). Charakter príspevku nie je prehl'adová či komparatívna štúdia zameraná na ozrejmenie organizačného a legislatívneho zabezpečenia týchto zariadení $v$ zahraničí, ale našim cielom je upriamit pozornost́ na to, ako sa STEM aktivity v týchto zariadeniach realizujú a hodnotia, a tým poukázat na možnosti realizácie STEM aktivít v našom prostredí (slovenskom a českom). Označenie poškolské programy/zariadenia používame na označenie realizácie aktivít mimo školského vyučovania (t.j. v čase po vyučovaní), avšak stále zabezpečované školou. $\mathrm{Z}$ toho dôvodu považujeme vyššie uvedené pomenovania za ekvivalent $\mathrm{k}$ našim ŠKD a ŠD.

\section{STEM AKTIVITY}

\section{A ICH HODNOTENIE}

Označenie $\mathrm{STEM}^{4}$ predstavuje anglický akronym pozostávajúci zo slov science (veda), technology (technológia), engineering (inžinierstvo) a mathematics (matematika). Vel'mi jednoducho možno povedat', že pokrýva prírodovednú a technickú oblast́ vo vzdelávaní. STEM sú považované za klúčové oblasti 21 . storočia pre dosiahnutie úspechu vo vzdelávaní a následne $\mathrm{v}$ d’alšej kariére, pre pokrok v inováciách, pre zachovanie hospodárskej konkurencieschopnosti, ochranu životného prostredia a účast' $\mathrm{v}$ demokratickej spoločnosti (Coalition for Science After School, 2007). Očakáva sa, že dopyt po odborníkoch pracujúcich v oblasti STEM sa do roku 2025 zvýši o 8\%, zatial' čo predpoved' priemerného rastu pre všetky povolania je 3\%. Avšak záujem o štúdium prírodovedných a technických smerov je stále nedostačujúci, predovšetkým v zastúpení žien (Caprile et al., 2015). Z toho dôvodu je potrebné zvyšovat záujem o STEM u žiakov nielen počas vyučovania, ale aj v neformálnom vzdelávaní.

Falkenberg, McClure \& McComb (2006) uvádzajú pät úspešných praktík používaných $\mathrm{v}$ poškolských STEM programoch: a) skúmanie vedy ${ }^{5}$ cez využitie bádania, b) skúmanie vedy prostredníctvom projektového a problémového učenia, c) integrácia vedeckej práce a skúmania do učebných osnov, d) zapojenie rodín a využívanie komunitných zdrojov, e) doučovanie zamerané na rozvoj vedeckého obsahu a zručností. Vel'mi jednoducho to zhrnuli Sahin, Ayar \& Adiguzel (2014), ktorí uviedli, že úspešnost́ týchto aktivít spočíva najmä $\mathrm{v}$ tom, že obsahujú dve zložky: praktickú a myšlienkovú.

\footnotetext{
${ }^{4}$ Pôvodný názov bol SMET - science (veda), mathematics (matematika), engineering (inžinierstvo) a technology (technológia; Sanders, 2009, in White, 2014).

${ }^{5}$ Označenie veda $\mathrm{v}$ príspevku vychádza z anglického pomenovania predmetu science, ktorý v sebe zahŕña prírodovedné predmety.
} 
Žiaci napríklad pri stavbe veže využívajú vzájomnú spoluprácu a komunikáciu, ktorú využili pri testovaní navrhnutých modelov pred začatím sútaže $\mathrm{v}$ triede.

Uvedené praktiky pokrývajú rôzne metódy - problémové, projektové vyučovanie či učenie objavovním. Spoločným menovatelom týchto metód je induktívny prístup $\mathrm{k}$ vzdelávaniu, pre ktorý je charakteristická predovšetkým aktivita učiaceho sa pri aplikovaní vedeckých postupov pri riešení výskumného problému/otázky. To znamená, že úloha učitela nie je odovzdat žiakovi „hotové" informácie, ale žiak sa k nim dopracuje sám. Pedagóg vystupuje $\mathrm{v}$ úlohe sprievodcu, resp. poradcu.

Rovnako aj $\mathrm{v}$ poškolských STEM programoch prevládajú aktivity, ktoré sú výskumne orientované a majú induktívny charakter (čo môžeme vidiet aj v spomenutých piatich bodoch). Napríklad Coalition for Science After School (2007) uvádza poškolské programy (Youth Exploring Science, Afterschool Science PLUS, After-School Math PLUS), ktoré realizujú výskumné a praktické aktivity zamerané na riešenie problémov, tvorivé myslenie a rozvoj vyšších myšlienkových operácií. Okrem toho sa vyznačujú tým, že sú pre žiakov zábavné, čo je $\mathrm{v}$ prostredí neformálneho vzdelávania dôležitým prvkom. $\mathrm{V}$ našich podmienkach môžeme spomenút napríklad výskumne ladenú koncepciu prírodovedného vzdelávania (inquiry based science education - IBSE), ktorá sa využíva už v materských školách.

$\mathrm{Na}$ druhej strane, pre mnohých učitel'ov/vychovávatel'ov, ktorí pôsobia v poškolských programoch, môže byt’ reali- zácia STEM aktivít zložitá, ba priam až problematická. Medzi najčastejšie bariéry možno zaradit napríklad nedostatok poznatkov o učebných osnovách a zdrojoch vhodných pre určitý vek; obmedzené prostriedky určené na materiál a vybavenie; nedostatočné a/alebo vôbec žiadne vedecké alebo prírodovedné vzdelanie učitel'ov/vychovávatel'ov (Ejiwale, 2013; Allan, 2018; ExpandED Schools, 2016). $\mathrm{V}$ nasledujúcom texte ukážeme, ako možno tieto prekážky prekonat a začat $s$ úspešnou realizáciou STEM aktivít, pričom sa zameriame (podla nás) na najviac problematické prvky:

- Obmedzené prostriedky určené na materiál a vybavenie - materiály využívanév STEM aktivitách nie sú zvyčajne drahé a častokrát ich nájdeme v každej domácnosti (napr. použité kelímky od jogurtov na konštrukciu šnúrového telefónu pre preskúmanie šírenia zvuku; rôzne druhy materiálu a balón na preskúmanie statickej elektriny; vyhotovenie padáku z mikroténového vrecka a šnúrky na prešetrenie volného pádu telies; pozorovanie hniezdenia vtákov v okolí školy a pod.).

- Strach z vedy u učitel'ov/vychovávatel'ov - ExpandED Schools (2016) zistili, že mnoho pedagógov, ktorí pôsobia v poškolských programoch, sa obáva realizácie STEM aktivít, pretože vedu považujú za nudnú a príliš akademickú, čo je pravým opakom aktivít, ktoré by sa mali realizovat $\mathrm{v}$ týchto programoch (aj v našich podmienkach vychádzame z rešpektovania najmä zásady dobrovol'nosti, záujmovosti a zaujímavosti). 
Avšak štúdia argumentuje tým, že mnoho z týchto pedagógov nemá ani umelecké či dramatické vzdelanie a napriek tomu nemajú problémy pri vedení a plánovaní týchto druhov aktivít. Je dôležité, aby videli, že rovnako aj STEM aktivity začínajú hrou a smerujú $\mathrm{k}$ disciplinovanej praxi, ktorá je zameraná na žiakov a je pre nich pútavá. $S$ týmto tvrdením súhlasíme, kedže postavenie pedagóga pri týchto aktivitách nie je vedúce, ale naopak, jeho úloha je žiakov usmerňovat pri hladaní otázok a odpovedí. Pedagóg má byt príkladom skúmajúcej a zvedavej osoby.

Samotná účasț žiakov v poškolskom programe však nestačí. Pre rozvoj žiakov je dôležitá účast́ predovšetkým vo vysoko kvalitných poškolských programoch (Mahoney, Levine \& Hinga, 2010, in Papazian et al., 2013; Allen et al., 2019). Ba naopak, účast́ v nekvalitných programoch môže negatívne ovplyvnit ich rozvoj (National Institute on Out-of-School Time, 2009).

Mnohí autori (Kahn, Bronte-Tinkew \& Theokas, 2008; Huang \& Dietel, 2011; Wilkerson \& Haden, 2014) sa venovali tomu, ako vytvorit úspešný poškolský STEM program, respektíve taký, ktorý by dosiahol vysokú kvalitu. Medzi znaky kvalitného STEM programu zarad'ujeme: 1. Prostredie a klíma - zabezpečit bezpečné a tvorivé prostredie pre žiakov.

2.Aktivity - majú praktický charakter a sú založené na skúmaní. Tiež by mali byt vzájomne prepojené - účast́ žiakov v poškolských zariadeniach môže byt nepredvídatel'ná, rozsah pozornosti je krátky. Pedagógovia by si mali vybrat obsah, ktorý je vhodný pre všetky vekové skupiny a ktorý sa nespolieha na predchádzajúcu účast́. Aktivity by sa však mali dat rozšírit' (po obsahovej aj časovej stránke), aby žiaci, ktorí majú záujem o d’alšie skúmanie, mohli na nich pracovat doma, prípadne na další deň.

- Aktivity zameriavat’ na žiakov - činnosti by mali vychádzat zo záujmov žiakov alebo by mali byt́ prepojené s ich každodenným životom. Taktiež by im mali poskytnút priamu skúsenost́ so skúmaným javom a materiálmi, pričom žiaci majú možnost́ využívat a aplikovat́ vedecké postupy.

- Aktivity sú v okruhu záujmu pedagóga - tento bod súvisí s vyššie spomenutými obavami pedagógov pri realizácii STEM aktivít. V tomto prípade možno začat s jednoduchými aktivitami, ktoré sa dajú implementovat l'ahko a zábavne.

\section{- Aktivity zapadajú do vzdelávacieho} programu školy - na naplnenie tohto bodu odporúčame komunikáciu s triednym učitel'om kvôli nadviazaniu na preberané učivo $\mathrm{v}$ škole. Týmto spôsobom si žiaci učivo zopakujú, precvičia a obohatia najmä o praktickú čast', na ktorú nemusí počas vyučovania zvýšit čas a priestor. Ak má pedagóg $\mathrm{v}$ poškolskom programe vekovo heterogénnu skupinu, môže aktivitu vystupňovat', resp. rozdelit ju do skupín podla náročnosti. Napr. pri skúmaní hustoty látok môžu najmladší žiaci všeobecne skúmat', ktoré predmety sa vo vode (ne) 
potopia. Starší žiaci môžu skúmat', ako napr. na plávanie predmetov vplýva ich tvar a materiál.

3. Vztahy - je dôležité rozvíjat', podporovat' a udržovat pozitívne vztahy a interakcie medzi všetkými účastníkmi, ktorí vstupujú do prostredia poškolského zariadenia, t.j. medzi zamestnancami, žiakmi a rodičmi, čo vedie $\mathrm{k}$ podpore pri plnení ciel'ov zariadenia.

\section{Profesionálny rozvoj zamestancov -} podporovat rozvoj pedagógov pôsobiacich $\mathrm{v}$ poškolskom zariadení, napríklad zabezpečovaním školení, spoluprácou s rôznymi zariadeniami a vzdelávacími inštitúciami (napr. univerzitami, múzea$\mathrm{mi})$, rodinou a pod., čo opät smeruje $\mathrm{k}$ napĺňaniu cielov poškolského zariadenia.

5. Limitované a špecifické ciele - v poškolských programoch je dôležité si stanovit taký počet cielov, ktoré je možné naplnit v čase, ktorý má pedagóg $\mathrm{k}$ dispozícii. Je dôležitejšie sa upriamovat na osvojenie si spôsobilostí u žiakov (napr. podporit rozvoj spôsobilostí vedeckej práce) ako sa zameriavat na osvojenie si obsahu teórie.

6.Dostupný materiál - ako sme už spomínali, pri STEM aktivitách je možno využit jednoduchý a dostupný materiál, ktorý môžu žiaci priniest́ z domu, prípadne si ho môžu odkladat́ pri pobyte v ŠKD/ŠD. Odporúčame zaobstarat si do triedy vel'kú krabicu, do ktorej budú žiaci spoločne odkladat́ rôzne predmety/materiály - krabičky z desiatej, kelímky z jogurtov, rôzne šnúrky, štuplíky a pod. V prípade po- treby bude mat pedagóg $\mathrm{k}$ dispozícii mnoho materiálu.

\section{Príležitost' posúdit' progres žiakov}

- materiál a zvolené aktivity by mali umožnit pedagógovi hodnotit žiaka za chodu. To môže pedagóg docielit napríklad tým, že bude klásť žiakom otázky zamerané na ich činnost', nechá žiakov samých vysvetlit jednotlivé kroky postupu ich práce a pod.

$\mathrm{Z}$ uvedeného možno povedat', že autori sa zhodovali predovšetkým v bodoch týkajúcich sa plánovania aktivít (stanovenie cielov), obsahu aktivít a personálneho zabezpečenia (požiadavky na pedagóga najmä z oblasti plánovania aktivít a odborných znalostí). Graficky to zhrnul Noam (2008, in Freeman et al., 2009; obr. 1), ktorý rozdelil klúčové vlastnosti vysokokvalitných poškolských programov do troch všeobecných oblastí: 1. aktivity, kurikulum a vzdelávanie; 2. kapacita personálu, odborná príprava a starostlivost o vztahy; 3. programové podporné štruktúry a vedenie. Pre vytvorenie kvalitného mimoškolského programu je potrebné oslovit všetky tri oblasti.

\section{Hodnotenie STEM aktivít v neformálnom vzdelávaní}

Ako sme uviedli vyššie, len účast́ v STEM aktivitách nepostačuje. $\mathrm{Z}$ toho dôvodu je dôležité poznat úroveň týchto aktivít a podporovat ich rozvoj smerom ku kvalite ako ku kvantite. To znamená, že vychovávatel' by mal uprednostnit kvalitne prepracovanú aktivitu realizovanú po- 

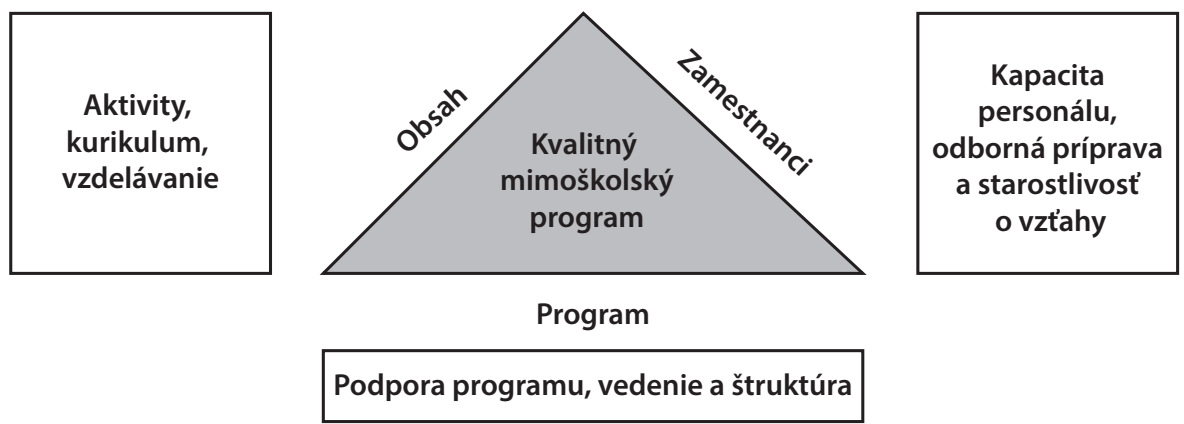

Obr. 1. Trojuholník kvality (Noam, 2008, in Freeman et al., 2009) ${ }^{6}$

čas celého pobytu v ŠKD/ŠD ${ }^{7}$ v režime dňa minimálne jedenkrát za dva týždne. ${ }^{8}$

Práve preto je potrebné poznat úroveň takýchto programov. Avšak ich hodnotenie nie je jednoduchou záležitostou, kedže sa realizuje $\mathrm{v}$ podmienkach neformálneho vzdelávania, a tým pádom nie sú presne stanovené požiadavky na obsah a podobu ich realizácie (mimo zarad’ovania režimových činností v školských výchovnovzdelávacích zariadení).

To, či sú STEM aktivity kvalitné, sa dá zistit ich systematickým pozorovaním. Ako uvádza Papazian et al. (2013), je dôležité identifikovat a definovat', čo je obsahom kvality programov, ktoré tieto aktivity zabezpečujú. Mnohé pozorovacie nástroje boli vyvinuté so zameraním na ich aplikáciu len počas vyučovania (nie v neformálnych podmienkach; Bill and Melinda Gates Foundation, 2012, in Papazian et al., 2013). Autori d’alej uvádzajú aj príklady takýchto nástrojov, napr. Reformed Teaching Observation Protocol (Piburn et al., 2000, in Papazian et al., 2013) a Classroom Observation Protocol (Weiss et al., 2003, in Papazian et al., 2013). U nás sa môžeme napríklad stretnút s hodnotením aplikácie výskumne ladenej koncepcie prírodovedného vzdelávania do vyučovania prostreníctvom pozorovacích hárkov zameraných na interakciu učitel'a a žiaka, na aktivitu žiakov, ale aj sebahodnotiaci nástroj pre učitela (Bergman et al., 2014).

Avšak hodnotiaci nástroj vytvorený čisto pre pozorovanie STEM aktivít v neformálnych podmienkach sa začal testovat

\footnotetext{
${ }^{6}$ Vol'ný preklad autora.

${ }^{7}$ Napríklad pozorovanie vtáčích druhov hniezdiacich v okolí školy - aktivitu možno tematicky rozčlenit aj do pohybovo-rekreačnej činnosti aj do odpočinkovej (príp. záujmovej) činnosti.

${ }^{8}$ Pri zarad'ovaní jednotlivých tematických oblastí výchovy (TOV) do výchovného plánu v SR sa dodržuje zásada, podla ktorej by sa mala každá TOV realizovat minimálne jedenkrát za dva týždne (Tvorba výchovných programov v školských zariadeniach, 2009).
} 
ešte len v roku 2007 v USA. Išlo o nástroj s názvom Dimenzie úspechu ${ }^{9}$ (Dimensions of Success - DoS), ktorý bol vytvorený výskumníkmi pôsobiacimi v Program in Education, Afterschool, and Resiliency (Papazian et al., 2013). Ako sme už uviedli, hodnotenie poškolských programov nie je jednoduchou úlohou. Preto bolo potrebné štandardizovat́ nástroj DoS. To sa mohlo uskutočnit vd’aka tomu, že americké úrady (National Science Foundation NSF, National Research Council - NRC) stanovili hlavné hodnotitel'né oblasti (motivácia žiakov a ich záujem o STEM, ich schopnost́ použivat modely a vytvárat́ vysvetlenia, skúmat' a testovat' otázky, reflektovat' a používat vedecký jazyk a vedecké nástroje, ich schopnost identifikovat sa ako ludia, ktorí sa môžu učit', používat' vedu a prispievat $k$ vede) a ciele neformálneho vzdelávania (Friedman, 2008, in Fu, Kannan \& Shavelson, 2019):

1. povedomie, znalost' alebo pochopenie konceptov, procesov alebo kariéry v STEM;

2.zapojenie sa alebo záujem o STEM koncepty, procesy alebo kariéru v STEM;

3. postoj $\mathrm{k}$ témam alebo schopnostiam súvisiacim so STEM;

4. správanie spojené so STEM konceptmi, procesmi či kariérou;

5. spôsobilosti založené na STEM konceptoch, procesoch alebo kariére.

Jednotlivé uvedené ciele pokrývajú oblast kognitívnu, afektívnu a psychomotorickú. Rovnako aj ciele prírodovedného vzdelávania sa dotýkajú uvedených oblas- tí, ktoré spoločne tvoria zložky vedeckej gramotnosti.

Výsledky DoS sa používajú dvomi spôsobmi. Po prvé, slúžia pre lepšie posúdenie silných a slabých stránok STEM programu a následne jeho zlepšenie, a po druhé, slúžia pre externých hodnotitelov na sledovanie kvality programov $\mathrm{v}$ určitom časovom horizonte, prípadne na porovnanie kvality programov v meste či celom štáte. Papazian et al. (2013) d’alej doplńajú, že pedagógovia, ktorí DoS používajú, sa dokázali pozriet na poškolské programy z iného uhla pohladu a uvádzali tiež, že sú si istejší pri realizovaní STEM aktivít. Taktiež uvádzali, že lepšie chápu, ako majú kvalitné STEM aktivity vyzerat. Jeden respondent uviedol, že pred vyskúšaním DoS nerobili vôbec výskumné aktivity a ani nevedeli, ako učit ich obsah. Venovali sa najmä tvorbe projektov.

Nástroj DoS obsahuje 12 indikátorov v štyroch okruhoch (znaky výučbového prostredia, zapojenie sa do činnosti, vedomosti a postupy v STEM a rozvoj mládeže v STEM) a bol testovaný v roku 2010 na viac než 300 STEM programoch $\mathrm{v}$ siedmich štátoch.

Prvé tri dimenzie $\mathrm{v}$ tabulke 1 (organizácia, materiály, využitie priestoru) sa zameriavajú na vlastnosti vzdelávacieho prostredia, ktoré sú dôležité pri plánovaní a realizácii STEM aktivít (napr. „Majú žiaci priestor na skúmanie? Sú materiály vhodné pre danú tému? Je časová organizácia vhodne rozložená?").

${ }^{9}$ Vol'ný preklad autora. 
Tab. 1. Dimenzie úspechu (DoS)

\begin{tabular}{|c|c|c|c|c|}
\hline \multirow{3}{*}{ Okruhy } & $\begin{array}{c}\text { Znaky výučbového } \\
\text { prostredia }\end{array}$ & $\begin{array}{c}\text { Zapojenie sa } \\
\text { do činnosti }\end{array}$ & $\begin{array}{c}\text { Vedomosti } \\
\text { a postupy v STEM }\end{array}$ & $\begin{array}{c}\text { Rozvoj mládeže } \\
\text { v STEM }\end{array}$ \\
\hline \multirow{3}{*}{ Dimenzie } & organizácia & participácia & $\begin{array}{c}\text { obsah učenia } \\
\text { STEM }\end{array}$ & vztahy \\
\cline { 2 - 5 } & materiály & $\begin{array}{c}\text { ciel'avedomé } \\
\text { činnosti }\end{array}$ & skúmanie & relevantnost́ \\
\cline { 2 - 5 } & využitie priestoru & $\begin{array}{c}\text { zapojenie sa } \\
\text { do STEM aktivít }\end{array}$ & uvažovanie & hlas mládeže \\
\hline
\end{tabular}

Ďalšie tri dimenzie (participácia, cielavedomé činnosti, zapojenie sa do STEM aktivít) sa zameriavajú na to, ako daná aktivita zapája žiakov do činnosti (napr. „Zapájajú sa všetci žiaci do aktivity? Dostávajú všetci žiaci príležitost́ zapojit sa do aktivity?")

Dimenzie v tretej oblasti (obsah učenia STEM, skúmanie, uvažovanie) sa zameriavajú na to, ako STEM aktivity realizované $\mathrm{v}$ rámci neformálneho vzdelávania pomáhajú žiakom porozumiet konceptom STEM a podielat sa na skúmaní a využívaní postupov, ktoré v praxi používajú vedci (napr. zhromažd’ovanie údajov, používanie vedeckých modelov).

Posledná oblast' a dimenzie v nej obsiahnuté (vztahy, relevantnost', hlas mládeže) hodnotí interakcie medzi pedagógom a žiakom a spôsob, akým povzbudzujú alebo odrádzajú žiaka od účasti na činnostiach STEM (napr. „Sú žiaci povzbudzovaní, aby vyjadrili svoje nápady/názory?"; The PEAR Institute, 2014).
Nástroj DoS obsahuje rovnaké oblasti a ciele neformálneho vzdelávania, ako uvádzajú NFS a NRC. Jediný rozdiel je len v tom, že spadajú do iných okruhov (Papazian et al., 2013). Avšak na to, aby mohol byt' DoS plnohodnotne a vhodne využívaný, záujemcovia musia prejst školením. Najprv sa zúčastnia dvojdňového školenia (osobne alebo online), aby sa naučili ako definovat a dodržiavat' kvalitu v každej dimenzii. Potenciálni pozorovatelia musia následne absolvovat celý rad video simulačných cvičení, aby si precvičili svoje znalosti o pozorovacom nástroji. PEAR ${ }^{10}$ (Partnerships in Education and Resilience) potom preskúma hodnotenia z týchto cvičení a poskytne im spätnú väzbu. Účastníci sa potom dohodnú na praktizovaní používania DoS v teréne $\mathrm{v}$ poškolských zariadeniach v ich miestnej oblasti. Po úspešnom splnení všetkých týchto požiadaviek získajú účastníci DoS certifikát na 2 roky. Celý tento zaškolovací proces trvá v rozmedzí od 2 týždňov do dvoch mesiacov.

\footnotetext{
${ }^{10}$ Inštitút PEAR (Partnerships in Education and Resilience) je nezisková organizácia vytvorená na podporu inovácií vo vzdelávaní, ktorú založil Dr. Gil G. Noam v roku 1999 ako spoluprácu medzi Harvardskou vysokou školou pre vzdelanie a Harvardskou lekárskou školou. Pozri bližšie https://www.thepearinstitute.org
} 


\section{Nástroj hodnotenia STEM aktivít pre žiakov}

Okrem pozorovacieho nástroja DoS bol vytvorený nástroj určený samotným žiakom, ktorí navštevujú tieto programy. Ide o nástroj $s$ názvom Common Instrument Suite (CIS; tab. 2), ktorý je určený pre žiakov vo veku 10 a viac rokov. Pôvodne bol vypracovaný pre použitie len $\mathrm{v}$ podmienkach neformálneho vzdelávania, avšak výskumy ukázali, že je možné ho využit aj počas vyučovania, t.j. vo formálnom vzdelávaní (The PEAR Institute,
2019). Pozostáva zo 14 otázok zameraných na posúdenie záujmu a ochoty zapájania sa do STEM a jeho vyplnenie trvá v rozmedzí od 5-20 minút. Výsledky z tohto prieskumu môžu byt užitočné pri tvorbe kvalitného poškolského programu zameraného na STEM.

V nástroji pre žiakov CIS sú uvedené len dve dimenzie, a to postoje spojené so STEM a schopnosti 21. storočia. V d'alšom sípci sú tieto dve dimenzie rozčlenené do špecifických oblastí, ktoré sú označované ako škála. Ďalší stĺpec definuje prostredníctvom otázok a definícií obsah

Tab. 2. Nástroj hodnotenia pre žiakov - Common Instrument Suite (Sneider \& Noam, 2019)

\begin{tabular}{|c|c|c|c|}
\hline Dimenzie & Škála & Definičné otázky & Príklad \\
\hline \multirow{6}{*}{$\begin{array}{l}\text { Postoje } \\
\text { spojené } \\
\text { so STEM }\end{array}$} & $\begin{array}{l}\text { záujem } \\
\text { o STEM }\end{array}$ & $\begin{array}{c}\text { Aký záujem a entuziazmus } \\
\text { prejavujú žiaci o STEM a aktivity } \\
\text { spojené so STEM? }\end{array}$ & $\begin{array}{c}\text { Mám rád aktivity zamerané } \\
\text { na STEM. }\end{array}$ \\
\hline & STEM identita & $\begin{array}{l}\text { Ako sa žiak vidí ako STEM } \\
\text { osoba? }\end{array}$ & Považujem sa za vedca. \\
\hline & $\begin{array}{l}\text { záujem o karié- } \\
\text { ru v STEM }\end{array}$ & $\begin{array}{c}\text { Ako je žiak motivovaný pracovat } \\
\text { v STEM oblasti? }\end{array}$ & $\begin{array}{l}\text { STEM mi pomôže nájst' si } \\
\text { v budúcnosti prácu. }\end{array}$ \\
\hline & $\begin{array}{l}\text { profesijné zna- } \\
\text { losti o STEM }\end{array}$ & $\begin{array}{c}\text { Ako je žiak informovaný o tom, } \\
\text { ako získat' kariéru v STEM? }\end{array}$ & $\begin{array}{l}\text { Poznám rôzne druhy vedec- } \\
\text { kých pracovných pozícií. }\end{array}$ \\
\hline & $\begin{array}{l}\text { potešenie } \\
\text { zo STEM }\end{array}$ & $\begin{array}{c}\text { Ako vel'mi si žiak užíva účast' } \\
\text { v aktivitách spojených so STEM? }\end{array}$ & $\begin{array}{c}\text { Rád sa zapájam } \\
\text { do vedeckých projektov. }\end{array}$ \\
\hline & STEM aktivity & $\begin{array}{l}\text { Ako často žiak vyhl'adáva STEM } \\
\text { aktivity? }\end{array}$ & $\begin{array}{l}\text { Pozerávam vedecké } \\
\text { programy v TV. }\end{array}$ \\
\hline \multirow{4}{*}{$\begin{array}{l}\text { Schopnosti } \\
\text { 21. storočia }\end{array}$} & $\begin{array}{c}\text { vztahy } \\
\text { s dospelými }\end{array}$ & $\begin{array}{c}\text { Pozivítne vztahy a postoje } \\
\text { smerom k interakcii s dospelými. }\end{array}$ & $\begin{array}{l}\text { Niektorí dospelí sa zaují- } \\
\text { majú o to, čo hovorím. }\end{array}$ \\
\hline & $\begin{array}{l}\text { vztahy } \\
\text { s rovesníkmi }\end{array}$ & $\begin{array}{l}\text { Pozitívne a podporné vztahy } \\
\text { s kamarátmi a spolužiakmi. }\end{array}$ & $\begin{array}{l}\text { Mám priatel'ov, ktorí sa } \\
\text { o mňa zaujímajú. }\end{array}$ \\
\hline & vytrvalost' & $\begin{array}{l}\text { Vytrvalost' v práci a riešenie } \\
\text { problémov napriek tažkostiam. }\end{array}$ & $\begin{array}{l}\text { Stále pracujem, aj ked’ to trvá } \\
\text { dlhšie, ako som si myslel. }\end{array}$ \\
\hline & $\begin{array}{l}\text { kritické } \\
\text { myslenie }\end{array}$ & $\begin{array}{l}\text { Preskúmanie informácií, predstáv } \\
\text { a nezávislého myslenia. }\end{array}$ & $\begin{array}{l}\text { Rád uvažujem iným spôso- } \\
\text { bom pri riešení problému. }\end{array}$ \\
\hline
\end{tabular}


škál. Tabul'ku uzatvárajú príklady výpovedí žiakov uvedených v poslednom stlpci.

Ako môžeme vidiet', úroveň zahraničných poškolských programov poskytujúcich STEM aktivity je posudzovaná a následne upravovaná za účelom dosahovania vysokej úrovne programov. Tieto kroky môžu predstavovat inšpiráciu pre naše prostredie, aby sme aj v rámci aktivít realizovaných v ŠKD a ŠD poskytovali žiakom aktivity, ktoré napomôžu rozvoju vedeckej gramotnosti. I ked' sa k vyššie uvedeným nástrojom nedopracujeme bez toho, aby sme neprešli školením, pedagógovia pôsobiaci v ŠKD a ŠD môžu v spolupráci $s$ triednym učitel'om pripravovat také aktivity, ktoré budú nadväzovat na školské vyučovanie nenásilným a predovšetkým zábavným spôsobom. Rovnako za prínosné pokladáme zohladnenie, resp. posúdenie jednotlivých dimenzií uvedených v tabul'ke 1 a 2 v rámci aktivít v ŠKD/ŠD. Vychovávatelia tak môžu vyhodnotit', ako (a či vôbec) dimenzie využívajú.

Navyše, pedagógovia nemusia mat́ obavy z nedostatku vedomostí a skúseností z oblasti STEM, kedže nemusia vystupovat' ako poskytovatelia odpovedí pre žiakov, ale spoločne s nimi hl'adat' odpovede na otázky. Odporúčame začínat s jednoduchými aktivitami, ktoré nevyžadujú časovú, materiálnu ani organizačnú náročnost'. Dôležitým prvkom, ktorý by tieto aktivity mali obsahovat, je proces skúmania, ktorý v sebe zahíňa kladenie si otázok a následne hladanie odpovedí na ne prostredníctvom využívania praktických aktivít. Aktivity by mali byt' tvorené zdôvodňovaním, predpokladaním, expe- rimentovaním, riešením problémov a reflexiou dôležitosti STEM v každodennom živote (National Research Council, 2015). Vel'mi výstižne to zhrnul pedagóg pôsobiaci v poškolskom programe vo výskume Huang a Dietel (2011, s. 5): „Zistili sme, že d’alšia úloha, ktorú musíme (zamestnanci) vykonávat', je zapojit deti do procesu učenia. Nejde teda len o dokončenie domácich úloh, ale aj o hladanie spôsobov, ako deti zaujat, nadchnút, aby sa cítili sebavedome a vybudovali si sebaúctu a aby sa chceli vrátit d’alší deň a skúsit to trochu tažšie."

\section{STEM AKTIVITY V NEFORMÁLNOM VZDELÁVANÍ A ICH VPLYV NA ŽIAKA}

Kvalitné poškolské programy prinášajú mnoho výhod predovšetkým pre ich účastníkov - žiakov. Benefity poškolských programov pre žiakov a ich rodiny dokazujú mnohé práce (Barker et al., 2003; Earle, 2009; Krishnamurthi, Ballard \& Noam, 2014). Medzi najčastejšie sa vyskytujúce výhody možno zaradit predovšetkým to, že poskytujú bezpečné prostredie pre deti, kým sú rodičia v práci, a že rozvíjajú akademické, sociálne a profesionálne zručnosti, ktoré žiaci potrebujú, aby uspeli v čoraz konkurenčnejšom prostredí globálnej ekonomiky. Prostredníctvom nich sa žiaci učia ako spolupracovat' a komunikovat' so svojimi rovesníkmi a učitel'mi odlišným spôsobom interakcie ako $\mathrm{v}$ bežných triedach (Mahoney, Cairns \& Farmer, 2003). Pravidelná účast' $\mathrm{v}$ poškolských programoch prispieva $\mathrm{k}$ formovaniu pracov- 
ných návykov a k znižovaniu nežiaducého správania (napríklad záškoláctva).

Kedže poškolské programy môžeme považovat za programy rešpektujúce najmä zásadu záujmovosti, je logické, že v poškolských STEM programoch žiaci rozvíjajú svoje záujmy v oblasti vedy, techniky, inžinierstva a matematiky, čo vplýva na výkon žiakov v škole a na výber ich budúceho povolania (National Research Council, 2015).

Avšak tieto programy sa prioritne nezameriavajú na zlepšenie školských výsledkov. Ich hlavným cielom je zapojit žiakov do praktických, aktívnych činností, a tým podporovat ich záujem o STEM (Neild, Wilson \& McClanahan, 2019). Aktivity v poškolských STEM programoch umožňujú žiakom lepšie pochopit vedecké pojmy, procesy a postupy (McGee-Brown et al., 2003, in Sahin et al., 2014). National Research Council (2015) označujú za jednu z výhod poškolských programov aj absenciu celoplošného (štandardizovaného) testovania, čo umožňuje väčšiu flexibilitu, a tým pádom povzbudzuje žiakov vstupovat do STEM programov.

Medzi d’alšie výhody realizácie STEM aktivít $\mathrm{v}$ poškolských programoch zarad’ujeme aj fakt, že žiaci prejavujú vo všeobecnosti pozitívny postoj smerom k STEM (veda, technika, inžinierstvo a matematika). Negatívny postoj, naopak, majú len k školskému STEM vyučovaniu (Papazian et al., 2013). Z týchto údajov môžeme vyvodzovat', že klasické vyučovanie STEM nie je pre žiakov atraktívne. A práve priestor ŠKD/ŠD môže priniest́ kompromis medzi klasickým vyučovaním STEM a tradičnou vedou. Poškolské pro- stredie ponúka príležitost́ spoznat' STEM zblízka pomocou zaujímavých materiálov, jednoduchých vedeckých nástrojov a metód vedeckého skúmania (Coalition for Science After School, 2007). Toto tvrdenie potvrdzujú napríklad aj Neild et al. (2019) alebo Duodu et al. (2017), ktorí uvádzajú, že žiaci zapojení do STEM programov rozvíjajú svoje záujmy v oblasti vedy, techniky, inžinierstva a/alebo matematiky. Okrem toho žiaci zlepšujú svoje školské výsledky, sú angažovanejší v škole a $\mathrm{v}$ neposlednom rade tieto programy podporujú rozvoj vedeckej gramotnosti (žiaci lepšie rozumejú vedeckým pojmom, procesom a postupom a rozvíjajú si spôsobilosti vedeckej práce; McGee-Brown et al., 2003, in Sahin et al., 2014).

$\mathrm{V}$ našom prostredí je celkom bežné, že oddelenia v ŠKD/ŠD sú tvorené vekovo nehomogénnou skupinou. Avšak práve to môže byt pri plánovaní a tvorbe STEM aktivít výhodou. Sahin et al. (2014) zistili, že tieto aktivity boli medzi žiakmi vel'mi populárne najmä preto, že sa nezameriavali len na učivo preberané $\mathrm{v}$ konkrétnych ročníkoch. Žiaci sa zúčastňovali aktivít preto, že ich jednoducho bavili a mali $\mathrm{z}$ nich radost́.

\section{STEM AKTIVITY v ŠKD A ŠD}

Rovnako ako na Slovensku, tak aj v Českej republike sa v zariadeniach zabezpečujúcich výchovu a vzdelávania mimo vyučovania stretávame $s$ režimom dňa, pozostávajúcim z režimových činností (odpočinkové, pohybovo-rekreačné, príprava na vyučovanie atd'.). 
Režim dňa sa v ŠKD a ŠD uskutočňuje podl'a zaužívaných (nepísaných) pravidiel. I ked' sa zväčša píše (Tvorba výchovných programov $\mathrm{v}$ školských zariadeniach, 2009) o striedaní času povinností s časom pre oddych, $\mathrm{v}$ praxi sa činnosti zaradujú (prevažne) nasledovne: poobede oddychová činnost', potom pohybovo-rekreačná a následne príprava na vyučovanie (SR, v ČR sa navyše zarad'uje aj záujmová činnost').

Ako sme už v úvode uviedli, STEM pokrýva prírodovedné a technické oblasti vo vzdelávaní. Priestor, v ktorom vidíme uplatnenie STEM aktivít v našom (slovenskom a českom) prostredí, je v rámci všetkých režimových činností (t.j. v odpočinkových, záujmových ${ }^{11}$ a pohybovo-rekreačných činnostiach). Konkrétne ide o ich využitie v prírodovedno-environmentálnej tematickej oblasti výchovy (Zájmové činnosti přírodovědně-ekologické) a pracovno-technickej tematickej oblasti výchovy (Zájmové činnosti pracovně-technické), ktoré sa zarad'ujú do spomenutých činností. V praxi sa často stretávame s tým, že obsah prírodovedno-environmentálnej TOV sa napíňa aktivitami typu triedenie odpadu, tvorba výtvarných produktov $s$ využitím prírodného materiálu, a v pracovno-technickej TOV ide najmä o aktivity zamerané na rozvoj manuálnych zručností (vystrihovanie, lepenie). Netvrdíme však, že uvedené typy aktivít sú nevhodné, či dokonca zlé. Vo výchovno-vzdelávacom procese (a najmä v podmienkach neformálneho vzdelávania) majú svoje opodstatnenie a miesto. Navrhujeme však, aby sa aktivity $\mathrm{v}$ uvedených oblastiach obohatili najmä o výskumné aktivity, ktorým možno prispôsobit režim dňa. Zaradením STEM aktivít do režimu dňa $\mathrm{v}$ týchto zariadeniach sa mimo iného napĺnajú ciele uvedených TOV, pričom pedagóg podporuje aj rozvoj vedeckej gramotnosti u žiakov.

$\mathrm{V}$ rámci týchto režimových činností je možné realizovat STEM aktivity, pričom pedagóg vychádza $\mathrm{z}$ výchovného programu (príp. „školního vzdělávacího programu ŠD") daného zariadenia. Aktivity v ŠKD a ŠD majú v porovnaní $s$ vyučovaním v škole praktickejší charakter. Oba výchovno-vzdelávacie procesy v SR (školské vyučovanie a ŠKD) vychádzajú zo štátneho vzdelávacieho programu. ${ }^{12} \mathrm{Aj}$ ked'ŠKD pracuje podl'a výchovného programu, ten prioritne vychádza zo štátneho, ale aj školského vzdelávacieho programu (ŠkVP). To znamená, že ŠKD potom napĺňa obsah ŠkVP praktickými aktivitami, ktoré majú vol'nejší a najmä hravejší charakter ako počas vyučovania.

Navyše, za výhodu týchto zariadení považujeme už vyššie spomenuté časové neobmedzenie realizácie aktivít, kedže sa tieto zariadenia neriadia triednohodinovým systémom. Zároveň je pre ne

\footnotetext{
${ }^{11}$ Záujmové činnosti sa nad’alej realizujú v Českej republike. Na Slovensku boli od roku 2013 vypustené z ŠKD a presunuté pod centrá vol'ného času.

${ }^{12}$ V ČR sa pri tvorbe školského vzdelávacieho programu ŠD vychádza z metodík tvorby ŠVP pre záujmové vzdelávanie (vydávaných Ministerstvom školstva, mládeže a telovýchovy), ktorý však nie je záväzný, a zo školského zákona, kde sú formulované povinné časti (napr. ciele, podmienky).
} 
charakteristická uvol’nenejšia atmosféra, ktorá vychádza z rešpektovania zásady záujmovosti a dobrovolnosti $\mathrm{v}$ týchto zariadeniach (Kratochvílová, 2010; Pávková, 2014). Aktivity je možné realizovat počas celého popoludnia, resp. možno ich prelínat cez všetky režimové činnosti.

Pedagógovia pôsobiaci v ŠKD a ŠD sa môžu pri realizácii STEM aktivít inšpirovat postupom pri aplikácii výskumne ladenej koncepcie prírodovedného vzdelávania (IBSE), ktorá je $\mathrm{v}$ našich podmienkach (vychádzame $\mathrm{z}$ vlastnej skúsenosti na základe počtu realizovaných školení pre pedagógov) pomerne známou koncepciou najmä v radoch učitelov predprimárneho vzdelávania a základnej školy. Ked'že vychovávatelia nemusia mat's danou koncepciou skúsenost', aj $\mathrm{v}$ tomto prípade odporúčame spoluprácu $s$ triednym učitelom. Koncepcia spĺňa požiadavky na STEM aktivity v neformálnom vzdelávaní (pozri bod $2 \mathrm{v}$ kapitole STEM aktivity a ich hodnotenie) a nevyžaduje žiadny špeciálny materiál. Aktivity v IBSE sa uskutočňujú cez tzv. algoritmus vedeckej práce (Held et al., 2011; Žoldošová, 2013). Vel'mi zjednodušene ho možno opísat nasledovne (vid' obr. 2): Začíname stanovením výskumnej otázky (problému), ktorú majú žiaci vyriešit'. Vel'mi vhodné je, ked' výskumná otázka vyplynula prirodzene z každodennej situácie, príp. udalosti, ktorú žiaci aktuálne riešia. Následne stanovujú svoje predpoklady a navrhujú spôsob, ako by mali po- stupovat pri ich overení a tým zodpovedat' výskumnú otázku (žiaci by mali navrhnút ako aj pomôcky, tak aj spôsob postupu). Potom svoje návrhy prakticky realizujú a vrátia sa k stanovenej výskumnej otázke, ktorú zodpovedajú.

Pre priblíženie uvádzame ukážku dvoch aktivít, ktoré možno prelínat cez viaceré režimové činnosti. Prvá aktivita „Vtáčie druhy vyskytujúce sa $\mathrm{v}$ okolí školy" sa viac zameriava na prírodovednú zložku (rozvoj prírodovedných predstáv, spôsobilosti vedeckej práce - cielené a detailné pozorovanie, vyhl'adávanie informácií vo viacerých zdrojoch, systematizácia pozorovaných skutočností), avšak môže vyústit aj do technickej oblasti (napr. konštrukciou vtáčej búdky/ kŕmidla). Druhá aktivita „Stavba veže“13 je zameraná najmä na technickú oblast́ (ide predovšetkým o rozvoj technického premýšlania, konštruovania, ale aj o rozvoj manuálnych zručností), pričom však žiaci využívajú aj prírodovednú oblast́ (vlastnosti papiera - jeho pevnost' a pružnost' v ohybe).

\section{Vtáčie druhy vyskytujúce sa v okolí školy}

Aktivitu možno začat už v oddychovej činnosti. V rámci nej vychovávatel' vedie so žiakmi rozhovor o tom, aké druhy vtákov žijú v našom prostredí - pýta sa ich na ich výzor, charakteristické znaky, kde žijú a pod. Následne nechá žiakom priestor

\footnotetext{
${ }^{13}$ Podobnú aktivitu sme realizovali v rámci projektu Technika hrou od MŠ a Technika hrou od ZŠ (https://pdf. truni.sk/katedry/kch/veda-vyskum?projekt-technika-hrou), avšak úlohou žiakov bolo postavit most z papiera. Prostredníctvom nej sa oboznámili s vlastnostami papiera.
} 


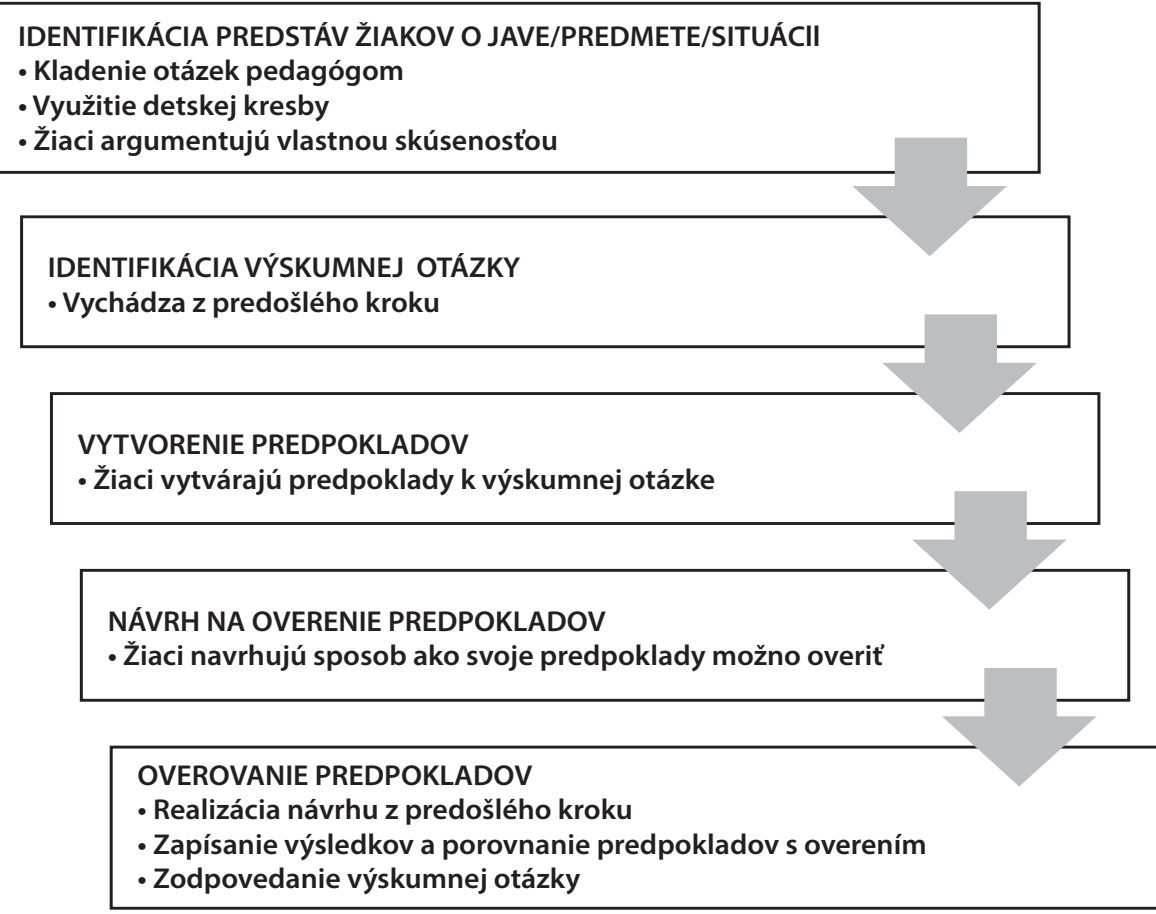

Obr. 2. Algoritmus vedeckej práce - zjednodušená podoba

na oddych, avšak so zameraním na tému. Poskytne žiakom rôzne encyklopédie, obrázky vtákov a pod. Každý žiak si môže zvolit lubovol'nú činnost' - kreslenie alebo čítanie, príp. počúvanie zvukov vtákov.

$\mathrm{V}$ pohybovo-rekreačnej činnosti realizuje vychovávatel' so žiakmi vychádzku v okolí školy. Úlohou žiakov je zodpovedat́ otázku, ktoré druhy vtákov sa vyskytujú/ hniezdia v okolí ich školy? Môžu využívat́ rôzne pomôcky - d'alekohl'ad, fotoaparát, knihu na určovanie živočíchov (napr. Vel'ká kniha živočíchov), zápisník, pero. $\mathrm{Z}$ pozo- rovania realizujú záznam - žiaci sa snažia opísat výzor jednotlivých druhov, stavbu hniezda, jeho umiestnenie, všímajú si aktivitu v hniezde (vajíčka, mlád’atá). Úlohou pedagóga je upriamovat pozornost́ žiakov na detaily (tým podporuje rozvoj spôsobilosti pozorovat - zo spontánneho pozorovania sa stáva cielené pozorovanie). V okolí umiestnenia hniezda môžu pohladat vtáčie perá (pierko si môžu v triede prekreslit, opísat' jednotlivé časti). Následne môžu spoločne vypracovat' mapu okolia školy (vo forme plagátu), do ktorej znázornia jednot- 
livé druhy vyskytujúce sa v blízkosti školy, ktorú umiestnia v triede.

Aktivitu možno následne rozšírit v priebehu roka (a aj nasledujúceho) tak, že žiaci budú dlhodobo pozorovat hniezda vtákov a zaznamenávat zmeny, ktoré môžu zaznačovat do hárku v podobe kalendára (zaznamenajú deň, čas, počasie, vonkajšiu teplotu, aktivitu pozorovaného druhu). $\mathrm{V}$ dohodnutých časových intervaloch (napr. raz za dva mesiace) vytvoria správu z pozorovania. Ďalej môžu odsledovat, ktoré druhy na zimu odlietajú, ktoré ostávajú, a vždy zaznamenajú približný dátum. Rovnako sa môžu zamerat na zistenie toho, kedy sa vracajú spät a či napríklad aj po návrate využívajú pôvodné hniezda (ak sú $\mathrm{k}$ dispozícii po ich návrate). Tiež môžu pozorovat', čo sa stanecez zimu s opustenými hniezdami (napr. či ich využijú iné druhy). Všetky zistené informácie zaznamenávajú do vytvorenej mapy. Podobným spôsobom môžu žiaci pokračovat aj doma a zapojit do aktivity rodičov.

Aktivitasa d’alej môže rozšírito manuálnu činnost́ - žiaci vytvoria vtáčie búdky/ kŕmidla pre druhy, ktoré ostávajú zimovat' v našom prostredí. Takto si vytvoria další priestor na pozorovanie vyskytujúcich sa druhov.

\section{Stavba veže}

Rovnako aj túto aktivitu možno začat' rozhovorom o rôznych typoch veží v oddychovej časti. Žiaci môžu diskutovat́ o tom, aké rôzne veže poznajú (betónové, kovové, drevené, železobetónové, kamenné), aký je ich tvar (hranol, valce) a aký je ich účel (maják, strážna veža, kostolná veža, televízna, rozhlasová veža, vrtná veža). Následne sa diskusia zameriava na posúdenie toho, ktorá čast' veže je podl'a žiakov najdôležitejšia (napr. stĺpy, opory výstuhy). Počas pohybovo-rekreačnej časti môžu realizovat vychádzku k veži, ktorá sa nachádza v blízkosti školy.

Následne, na druhý deň, bude úlohou žiakov navrhnút a následne skonštruovat́ vežu z kancelárskeho papiera. Tvar veže je lubovolný. Úlohou žiakov bude vytvorit čo najvyššiu vežu - d'alšie podmienky môže upravit vychovávatel' (aby sa dala veža preniest́, aby sa nenakláňala do žiadnej strany a pod.). Veže môžu v závere testovat' tak, že ich bud' postavia vedl'a seba a porovnajú, alebo ich spoločne $s$ vychovávatelom premerajú výsuvným metrom. Žiaci pracujú v skupinách (3-5 členov). Každá skupina má k dispozícii 10 listov kancelárskeho papiera (počet listov a druh papiera je možné prispôsobit'), nožnice, pravítko, lepidlo / lepiacu pásku. Vychovávatel' žiakov upozorní na to, že v prípade poškodenia papiera d’alší nedostanú - tým podporí ich snahu si konštrukciu najskôr premysliet́ a načrtnút. Pri konštrukcii môžu papier l'ubovol'ne skladat', strihat', lepit́. Pred samotnou realizáciou veže však musí každá skupina prekonzultovat a načrtnút svoj návrh, ktorý odprezentuje pred celou triedou. Svoje návrhy odôvodnia (mali by vysvetlit', na základe čoho si myslia, že ich veža bude najstabilnejšia a najvyššia). Vyhrá tá skupina, ktorej veža je najvyššia a spĺňa dohodnuté kritériá. $\mathrm{V}$ závere spoločne prediskutujú, prečo podla nich vyhrala práve tá konkrétna 
veža, čo je podl'a nich najdôležitejšie pri jej konštrukcii. Vychovávatel' môže žiakov d’alej vyzvat', či by vedeli svoje veže (na základe záverečnej diskusie o vítaznej veži) vylepšit, aby boli napríklad stabilnejšie, pevnejšie.

\section{ZÁVER}

STEM sa javí pre žiakov atraktívnou oblastou, najmä čo sa týka neformálneho vzdelávania. Túto skutočnost́ je dôležité využit z dôvodu neustáleho poklesu záujmu o STEM ako o oblast́ budúceho povolania. Je zrejmé, že STEM bude v budúcnosti vel'mi žiadanou a dopyt po zamestnancoch bude velký. ŠKD a ŠD ponúkajú priestor na realizáciu STEM aktivít, pričom pedagóg bude napĺňat ciele výchovného programu a zároveň podporovat rozvoj vedeckej gramotnosti.

Tento krok sa dá docielit tak, že aktivity sa budú orientovat najmä na proces skúmania. To znamená, že žiaci budú kopírovat činnost' vedcov pri vyriešení výskumného problému či otázky. Pedagógovia však nemusia mat obavu z nekompetentnosti v tejto oblasti. Ich úlohou nie je zodpovedat výskumnú otázku či problém namiesto žiakov. Naopak, žiakov sprevádzajú a spoločne s nimi sa snažia problém vyriešit'. Ak sa pe- dagóg rozhodne realizovat STEM aktivity v ŠKD/ŠD, odporúčame začat s jednoduchými aktivitami, najlepšie takými, ktoré vychádzajú zo záujmov žiakov a pedagóga. Rovnako odporúčame spolupracovat s triednym učitelom a tak nadviazat na vzdelávací proces počas vyučovania. Pri plánovaní aktivít môžu pedagógovia posudzovat dimenzie uvedené v DoS, ako je napr. využívanie materiálu, priestoru, zapájanie žiakov do činnosti alebo už spomenuté skúmanie. I ked' si výskumné činnosti môžu žiadat viac času, práve ŠKD a ŠD majú výhodu časového neobmedzovania - aktivity možno prispôsobit celému režimu dňa. V prípade záujmu môžu žiaci pokračovat́ $\mathrm{v}$ domácom prostredí a tak zapájat do aktivít aj rodičov.

Vhodnou pomôckou pre pedagógov pri implementovaní výskumných aktivít je využitie algoritmu vedeckej práce, ktorý opisuje postup pri aplikácii výskumne ladenej koncepcie do vyučovania (IBSE). Náročnost aktivít v IBSE je možné prispôsobit vekovej skupine žiakov. Aktivity predstavujú pre žiakov hru, prostredníctvom ktorej sa učia.

Po začlenení STEM aktivít do režimu dňa majú ŠKD a ŠD potenciál zaplnit medzery v školských schopnostiach žiakov a dalej podporovat a prehlbovat ich záujem o STEM.

\section{LiteratúRA}

Allan, A. (2018). Tips for great STEM afterschool. National AfterSchool Association. (Online). Dostupné z https://naaweb.org

Allen, P. J., Chang, R., Gorrall, B. K. et al. (2019). From quality to outcomes: a national study of afterschool STEM programming. International Journal of STEM Education, 6, 37.

Barker, J., Smith, F., Morrow, V., Weller, S., Hey, V., \& Harwin, J. (2003). The impact of out-of-school care: A qualitative study examining the views of children, families, and play 
workers. Department for Education and Skills (DfES). (Online). Dostupné z https:// webarchive.nationalarchives.gov.uk

Bergman, G., et al. (2014). Diagnostické nástroje na podporu výskumne ladenej koncepcie v prírodovednom vzdelávaním. Trnava: Pedagogická fakulta Trnavskej univerzity.

Caprile, M., Palmen, R., Sanz, P., \& Dente, G. (2015). Encouraging STEM studies for the labour market. Directorate-General for Internal Policies: European Parliament. Dostupné z www.europarl.europa.eu

Coalition for Science After School (2007). Science in After-School. New York, NY: The After-School Corporation.

Duodu, E., Noble, J., Yusuf, Y., Garay, C., \& Bean, C. (2017). Understanding the delivery of a Canadian-based after-school STEM program: a case study. International Journal of STEM Education, 4, 20.

Earle, A. (2009). Roadmap to afterschool for all: Examining current investments and mapping future needs. Washington, D.C.: Afterschool Alliance. Dostupné z www.afterschoolalliance.org

Ejiwale, J. (2013). Barriers to successful implementation of STEM education. Journal of Education and Learning, 7(2), 63-74.

ExpandED Schools. (2016). STEM after school. How to design and run great programs and activities. A guidebook for program leaders. 2. vyd. New York.

Falkenberg, K., McClure, P., \& McComb, E. M. (2006). Science in Afterschool Literature Review. Chapel Hill: University of North Carolina,.

Freeman, J., Dorph, R., Chi, B. (2009). Strengthening after school STEM staff development. Berkeley: University of California,. Dostupné z www.informalscience.org

Fu, A. C., Kannan, A., \& Shavelson, R. J. (2019). Editors' notes. New Directions for Evaluation, $161,7-15$.

Held, L. et al. (2011). Výskumne ladená koncepcia prírodovedného vzdelávania (IBSE v slovenskom kontexte). Bratislava: VEDA.

Huang, D., \& Dietel, R. (2011). Making afterschool programs better. CRESST Policy Brief. Los Angeles: University of California.

Kahn, J., Bronte-Tinkew, J., \& Theokas C. (2008). How can i assess the quality of my program? Tools for out-of-school time program practitioners. Child Trends Brief Research to Results, 10.

Kratochvílová, E. (2010). Pedagogika volného času. Výchova v čase mimo vyučovania v pedagogickej teórii a praxi. Trnava: Typi Universitatis Tyrnaviensis.

Krishnamurthi, A., Ballard, M., \& Noam, G. G. (2014). Examining the impact of afterschool STEM programs. Washington, DC: Afterschool Alliance.

Mahoney, J. L., Cairns, B. D., \& Farmer, T. W. (2003). Promoting interpersonal competence and educational success through extracurricular activity participation. Journal of Educational Psychology, 95(2), 409-418. 
Memorandum o celoživotnom vzdelávaní sa. Brusel: Komisia európskych spoločenstiev, 2000. National Institute on Out-of-School Time. (2009). Making the case: A 2009 fact sheet on children and youth in out-of-school time. Wellesley College Center for Research on Women. Dostupné $\mathrm{z}$ www.niost.org

National Research Council. (2015). Identifying and supporting productive STEM programs in out-of-school settings. Washington, DC: National Academies Press.

Neild, R. C., Wilson, S. J., \& McClanahan, W. (2019). A companion to afterschool programs: A review of evidence under the Every Student Succeeds Act. Afterschool Evidence Guide. Philadelphia: Research for Action.

Papazian, A. E., Noam, G. G., Shah, A. M., \& Rufo-McCormick, C. (2013). The quest for quality in afterschool science: The development and application of a new tool. Afterschool Matters, 18, 17-24.

Pávková, J. (2014). Pedagogika volného času. Praha: Pedagogická fakulta UK.

Sahin, A., Ayar, M. C., \& Adiguzel, T. (2014). STEM related after-school program activities and associated outcomes on student learning. Educational Sciences: Theory and Practice, 14(1), 309-322.

Sneider, C., \& Noam, G. G. (2019). The common instrument suite: A means for assessing student attitudes in STEM classrooms and out-of-school environments. Connected Science Learning, 11.

The PEAR Institute: Partnerships in Education and Resilience. (2014). An introductory guide to the Dimensions of Success (DoS) observation tool. (Online). Dostupné $\mathrm{z}$ https://nmost.org

The PEAR Institute: Partnerships in Education and Resilience. (2019). A guide to PEAR's STEM tools: Common instrument suite \& dimensions of success. Cambridge, MA: Harvard University.

Tvorba výchovných programov v školských zariadeniach (ukážka). (2009). Bratislava: Štátny pedagogický ústav. Dostupné z www.minedu.sk

White, D. W. (2014). What is STEM education and why is it important. Florida Association of Teacher Educators Journal, 1(14), 1-9.

Wilkerson, S. B., \& Haden, C. M. (2014). Effective practices for evaluating STEM out-of-school time programs. Afterschool Matters, 19(1), 10-19.

Žoldošová, K. (2013). Primárne prirodovedné vzdelávanie. Pedagogická fakulta Trnavskej univerzity v Trnave.

Mgr. Michaela Bieliková, PhD.

Trnavská univerzita v Trnave, Pedagogická fakulta;

e-mail: michaela.bielikova@truni.sk 


\section{BIELIKOVÁ, M. Implementation of STEM Activities in School Educational Facilities}

This theoretical study focuses on the possibilities of the realization of STEM (Science, Technology, Engineering, and Mathematics) activities in non-formal education, specifically in after-school clubs (Slovak Republic) and school clubs (Czech Republic). In this paper we focus on the way STEM activities in after-school clubs, out-of-school clubs, and afterschool programmes are realized and evaluated, as well as the impact of these activities on the pupil (benefit, behaviour, socialization, etc.).

We believe that we can apply these activities (in our environment - Slovak and Czech) in several spheres of activity, for example in relaxation, interest, and physical-recreational activities, particularly in the science-environmental thematic area of education (Science-ecological interest activities) and work-technical thematic area of education (Work-technical interest activities) which are included in the aforementioned activities. We see extended possibilities (spatial and temporal) in the implementation of STEM activities compared to traditional teaching in these facilities where the teacher is limited mainly by a class hour system.

Keywords: evaluation, afterschool programmes, STEM activities, school club, after-school club 